\title{
THE IMPORTANCE OF GEOGRAPHIC ACCESS FOR THE IMPACT OF MICROFINANCE
}

Nargiza Alimukhamedova Randall K. Filer Jan Hanousek

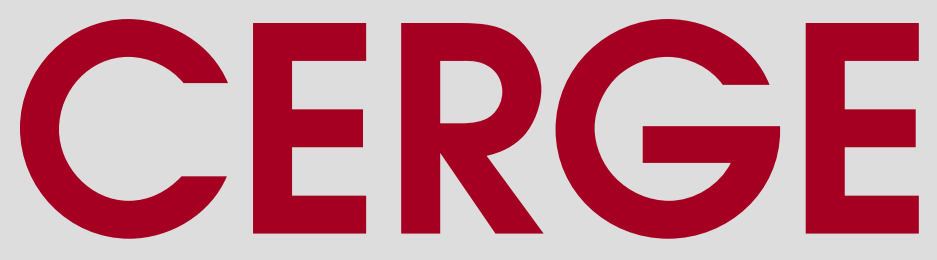




\section{Working Paper Series 577 (ISSN 1211-3298)}

\section{The Importance of Geographic Access for the Impact of Microfinance}

Nargiza Alimukhamedova

Randall K. Filer

Jan Hanousek

CERGE-EI

Prague, November 2016 
ISBN 978-80-7343-384-0 (Univerzita Karlova, Centrum pro ekonomický výzkum a doktorské studium)

ISBN 978-80-7344-400-6 (Národohospodářský ústav AV ČR, v. v. i.) 


\title{
The Importance of Geographic Access for the Impact of Microfinance ${ }^{1}$
}

\author{
Nargiza Alimukhamedova ${ }^{\mathrm{a}}$, Randall K. Filer ${ }^{\mathrm{b}}$, Jan Hanousek ${ }^{\mathrm{c}}$
}

November 2016

\begin{abstract}
The geographic distance between a household and financial institutions may constitute a significant obstacle to achieving the benefits of modern financial institutions. We measure the impact of distance-related access to microcredits in Uzbekistan. Residents living closer to microfinance institutions are propensity score matched to those further away using both household and village characteristics. Households located nearer to microfinance institutions have larger businesses in terms of income, profits and employees than similar households located further away. In addition, they spend more on most forms of consumption and have greater savings.
\end{abstract}

JEL Codes: O16, C34

Keywords: microcredit, microfinance institutions, geographic access

\footnotetext{
1 The authors would like to thank the participants of Bratislava Economic Meeting 2012 Conference, the Institute for East and Southeast European Studies research seminar, the University Meets Microfinance (UMM) Project of the European Microfinance Network workshops in Hannover and Frankfurt, the Economics Education and Research Consortium (EERC) Research Workshop in Kiev, and the Research Seminar at the Westminster International University in Tashkent for helpful comments and suggestions. Nargiza Alimukhamedova greatly acknowledges the financial support from the Grant Agency of Charles University (grant No. 586912), the Global Development Network (implemented jointly by the CERGE-EI Foundation and EERC), as well as UMM project scholarship. Jan Hanousek research was supported by GAČR grant No. 14-31783S. All opinions expressed and errors remaining are the responsibility of the authors and do not reflect the views of any of the supporting institutions.

a CERGE-EI, Charles University and the Czech Academy of Sciences, Prague, Czech Republic; Prague School of Economics, Department of Institutional, Environmental and Experimental Economics; Westminster International University in Tashkent, nargiza@cerge-ei.cz b Department of Economics, Hunter College and the Graduate Center, The City University of New York, CERGE-EI, Charles University and the Czech Academy of Sciences, Prague, IZA, Bonn, CESifo, Munich, rfiler@hunter.cuny.edu

c Corresponding author: CERGE-EI, Charles University and the Czech Academy of Sciences, Prague, Czech Republic; CEPR, London, jan.hanousek@cerge-ei.cz
} 


\section{Introduction and Motivation}

According to Demirguc-Kunt and Klapper (2012), around 2.5 billion individuals, roughly half of the world's adult population, do not have a formal bank account. This situation results from various obstacles including information asymmetries between borrowers and lenders, costs of transactions, and legal and geographic barriers.

Over recent decades, the microfinance movement has gained increasing attention as a tool for economic development. Numerous studies have measured the impact of microcredit on microenterprises and consumer well-being. ${ }^{2}$ Recent randomized control trials that offer methodologically robust measures of microfinance's impact suggest that better access results in modest but positive effects on household socio-economic indicators including labour supply, women's empowerment and children's schooling. A summary of six randomized trials from developing countries is presented by Banerjee, Karlan, and Zinman (2015). Other such results are available for Ethiopia (Tarozzi, Desai, \& Johnson (2015), and Mexico (Angelucci, Karlan, \& Zinman (2015)).

We add new evidence to this literature by studying microfinance in Uzbekistan. Our contribution includes : (1) evidence from a new setting where microfinance evolved in a nontradition way based on private and commercial considerations, (2) robust measures of microfinance's impact that address demand and supply-side selection issues using retrospective data, and (3) policy relevant findings that could be helpful in deciding the location of microfinance institutions.

Our objective is to estimate the effect of distance-related access to microcredits in Uzbekistan. Households residing in the closest distance quartile from a microfinance institution (MFI) in our sample are propensity score matched with ones in the furthest

\footnotetext{
${ }^{2}$ See Bauchet, Marshall, Starita, Thomas, \& Yalouris (2011) for a summary of early empirical findings.
} 
quartile. ${ }^{3}$ To ensure proper matching, initial level covariates are re-created using a set of retrospective questions from a cross-sectional survey conducted especially for this study. The accuracy and memory recall of retrospective data is enhanced by the use of "fundamental events" that are discrete and significant in the life of households and, therefore, should be easily recalled by respondents. Supply-side selection stemming from non-random placement of MFIs is addressed by controlling for district level characteristics.

Our findings indicate that households with better access (closer geographic proximity) to an MFI run more profitable enterprises with significantly greater income and more employees. They also consume more in most categories and have amassed greater savings. Combined, these results suggest a strong positive role for MFIs in improving well-being.

These results have policy relevance for expanding access to finance and microfinance institutions. In particular, the location of a new MFI or branch network expansion of an existing MFI should not be made randomly but should take account potential demand. Location in areas of high demand may seem contradictory to the apparent mission of microfinance that deliberately located institutions in remote areas to support lower-income households, but given limited budgets may enhance actual benefits.

\section{Literature Review}

In most developing countries, geographic or physical access is among the main barriers that prevent small businesses and poor households from accessing financial services. While some financial institutions allow clients access over telephone or via the Internet, most financial institutions including MFIs require clients to visit a branch, ensuring repayment and collection of hard and soft information (Demirguc-Kunt, Beck, \& Honohan, 2008; Presbitero \& Ravellotti, 2014).

\footnotetext{
${ }^{3}$ These are explicitly not the most distant from an institution in the country as a whole since the sample was, as discussed below, collected only from specific districts. It would be expected, therefore, that the impact of universal access could be substantially greater than that found here.
} 
Although the role of geographic distance has been widely investigated in commercial banking as a proxy for transportation costs and informational asymmetries between lenders and borrowers (Allesandrini, Fratianni \& Zazzaro, 2009), the geographic outreach of MFIs has been less studied, mainly due to an assumption that MFIs are embedded in the communities in which they operate (Bateman \& Chang, 2009). Gulli and Berger (1999), however, find that poor infrastructure, unfavourable geographic conditions, and low population density hinder the outreach of MFIs in remote and rural areas.

The few studies that have evaluated the impact of the distance on loan repayment rates find contrasting results. While distance was negatively correlated with microcredit repayment in Nigeria (Oke, Adeyemo, \& Agbonlahor, 2007), this effect was not found in Malaysia (Roslan \& Karim, 2009). Pedrosa and Do (2011) provide evidence from Niger, where, in response to lower quality information about more distant loan applicants, MFIs adopt more restrictive loan conditions, higher interest rates and more intensive screening. Barboza and Trejos (2009) find that rural Mexican MFIs have significantly greater levels of group lending and peer monitoring. Presbitero and Rabellotti (2014) estimate the effect of the distance to a microcredit institution on a borrower's self-assessed outcome in Colombia and find that moral hazard increases with the distance from microcredit institution.

Two recent non-experimental studies examine the impact of geographical distance to an MFI on financial inclusion. Allen et al. (2013) employ a household survey and bank penetration data from Equity Bank in Kenya. The findings suggest that local presence has a positive and significant impact on households' use of bank accounts and credit, especially for those who are ignored by traditional commercial banks. Brown, Guin, and Kirshenmann (2013) study the expansion of the branch network of ProCredit banks in Southeast Europe between 2006 and 2010. In particular, they examine how geographic proximity to a microfinance bank affects the use of bank accounts by low-income households. The findings 
suggest that microfinance banks promote financial inclusion even in these relatively more developed emerging markets even where conventional banks are active.

Among the studies that have measured the impacts of microcredit, there are five prominent examples that have focused on the impact of programs targeting micro entrepreneurs, typically by requiring business plan as a part of the loan application. Details and summaries can be found in Banerjee et al. (2015) and Bauchet et al. (2011).

In general these studies find a modest impact on health, education and female empowerment. A particular important point in our context is that there was a clear heterogeneous impact with regard to entrepreneurship activity whereby existing business entrepreneurs reduce consumption and considerably increase savings when given access to microcredit, while non-entrepreneur clients increased consumption.

\section{Country Context}

Uzbekistan is a lower middle-income country located in the heart of Central Asia and a former member of the Soviet Union, having gained independence in 1991. With $30.24^{4}$ million inhabitants, the country accounts for almost 40 per cent of the population of the Central Asian region. Microfinance programs in the country were first pioneered by the United Nations Development Program in 1998, with the conventional missions of alleviating poverty, smoothing the transition, and boosting employment, especially in remote areas. Between 1998 and 2011, however, the microfinance landscape in Uzbekistan changed substantially, driven mainly by legal changes restricting the participation of foreign NGOs. ${ }^{5}$ Before official termination in October 2011, MFIs in Uzbekistan consisted of two types, both of which were private and profit-oriented. Credit unions (CUs) issued microcredits to individuals for both business and consumption needs and attracted deposits. Unlike standard international practice, in Uzbekistan CUs were open to the general public and not limited to a

\footnotetext{
${ }^{4}$ Source: World Bank 2015 estimates, based on http://data.worldbank.org/country/uzbekistan?display=graph ${ }^{5}$ See Alimukhamedova (2014) for a detailed description of the evolution of the microfinance environment in the country.
} 
defined, closed membership group. On the other hand, Microcredit Organizations (MCOs) operated similarly to Grameen-type group lending institutions, using joint liability and a small collateral requirement with dynamic incentives and disproportionate female participation. Together, CUs and MCOs occupied a niche between commercial banks and informal money lenders. ${ }^{6}$ The average loan size was USD 2200 for CUs and USD 530 for MCOs, compared to USD 3500 for commercial bank small loans. These differences are clearly linked to the ability of Credit Unions to accept deposits, leading them to focus on the economically better off clients who desire both deposit and lending services (either simultaneously, at varying times in the business cycle or in the development of their businesses).

Given local regulations, unlike canonical microfinance lending supported by international donors and utilizing subsidies to reduce poverty and target low-income households, in Uzbekistan non-bank MFIs targeted economically active households, typically those above the official poverty line (United Nations Development Program, 2011). Therefore, different effects on business and consumption outcomes might be expected from those of canonical microlending.

Several indicators have been used in previous studies to measure geographic access to finance, including average distance from a household to the nearest branch (or ATM), density of branches per square kilometre or per capita, and average time necessary for a borrower to reach an MFI branch (Demirguc-Kunt et al., 2008). We measure geographic access to microcredit by the distance in kilometres to the nearest non-bank MFI. Transportation barriers are likely to be particularly severe in Uzbekistan. The population density of 61 per square kilometre is low. The country has an average of $18 \mathrm{~km}$ of roads per every $100 \mathrm{sq} \mathrm{km}$ of land mass (as opposed to a world average of 33) and private auto ownership rates are low

\footnotetext{
${ }^{6}$ Average borrowings from informal sources were at most $50 \%$ of those from the smallest type of formal financial institution.
} 
(37 per 1000 population). Even in urban areas, transport costs are likely to pose barriers for the poor. As of 2013, the cost of a monthly transit pass for a pensioner in Tashkent was over 25 per cent of the minimum pension, while for a working-age person a monthly public transit pass cost over 50 per cent of the minimum wage and about 15 per cent of the average wage.

It should be stressed that issue of physical barriers to MFIs is of particular importance in case of Uzbekistan. Difficulties in reaching the nearest MFI in urban areas could be created by extra waiting time in traffic or the requirement of travelling to another part of the city which is one of the largest megapolises in Central Asia. Traveling in rural areas, geographical obstacles are even more dramatic due to heterogonous landscape and limited infrastructure. For example, Fergana valley (one of our surveyed regions) lies in a natural bowl surrounded by the mountain ranges of Tien-Shan in the north and Gissar-Alai in the south. There is a single tunnel between Tashkent and Fergana valley, a journey that take almost six hours by car.

\section{Methodology}

Access to microcredit can affect both business and consumption behaviour. In our sample, 75 per cent of credits from MCOs and 60 per cent of credits from CUs are reportedly used for small business expansion, including the purchase of raw materials and inventory (Alimukhamedova, 2012). Examining both business and consumption responses is necessary, however, because credits are fungible within households such that money nominally borrowed for business purposes may be used instead to cover other household expenses (Karlan \& Goldberg, 2011).

There are two sources of bias that create inconsistent estimates of the causal impact of microfinance programs: (i) demand-side selection whereby microfinance clients are not a random sample of the population but are self-selected into MFIs based on unobserved characteristics, and (ii) supply-side selection, implying that MFIs are non-randomly 
established in districts. Demand-side selection has been addressed using both experimental, (randomized control trials (RCT)) and non-experimental methods. Detailed overviews and discussion of the trade-off between experimental and non-experimental studies can be found in Smith and Todd (2005) and Dehejia and Wahba (2002), while specific applications in the microfinance context are discussed in Armendariz and Morduch (2010) and Armendariz and Labie (2011).

We employ propensity score matching as a second best solution to address demand side selection bias in the absence of experimental intervention (Rosenbaum and Rubin, 1983). ${ }^{7}$ The notion of "treatment" in our case is based on the distance to the nearest non-bank MFI. Each household among the 25 per cent residing the closest to an MFI in our sample is matched with a household among the 25 per cent residing the farthest using a set of pretreatment covariates including both household characteristics and MFI location determinants. We use kernel matching ${ }^{8}$ with replacement, which has a major advantage of lower variance given that the common support condition is fully satisfied (Caliendo \& Kopeinig, 2008) as it is for all estimates reported below. Effectively, we provide a modified Intention-to-treat (ITT) estimate where intensity is measured as strong or weak (according to distance) rather than present or absent.

The direction of supply-side selection bias due to the non-random placement of microfinance institutions is uncertain (Hulme \& Mosley, 1996; Armendariz \& Morduch, 2010). Povertyoriented donor MFIs tend to be established in poorer areas, thus causing a

\footnotetext{
${ }^{7}$ While matching is probably the second best solution for impact assessment in the absence of experimental design, alternative could be a regression analysis using instrumental variables to control for selection and endogeneity of microcredit participation decision. The regression approach, however, imposes strong functional form (linearity) over the common support area while matching is non-parametric. Effectively, what matters the most is not the estimation method itself (regression or matching), but whether the data is balanced. The latter is ensured in p-score matching, and is, in general, verified in our results. As an alternative, we attempted a twostage least square [2SLS] analysis, instrumenting an "easy-difficult access" treatment dummy in the first stage with residuals saved from Truncated Poisson regression estimation results predicting placement of non-bank MFIs in Uzbekistan (Alimukhamedova, 2014). The instrument however did not pass the Sargan test for overidentifying restrictions and results are, therefore, not reported.

${ }^{8}$ Using a quadratic kernel and a default bandwidth of 0.06 .
} 
downward bias in measured impacts on income-related outcomes. In contrast, an upward supply-side bias could stem from profit-oriented MFIs locating in economically advantageous areas or places with better credit infrastructure.

The first microcredit institutions in Uzbekistan were pioneered by international donors for non-profit purposes and were located deliberately in poor and remote areas. Further information on the uneven distribution of non-bank MFIs can be found in Alimukhamedova (2014). Table 1 summarizes the distribution of all MFIs in the country. Three-quarters of institutions are located in rural areas and districts and only a quarter are in cities or urban areas.

Table 1. Location of non-bank MFIs

\begin{tabular}{clcc}
\hline \hline $\begin{array}{l}\text { Non-bank } \\
\text { MFIs: }\end{array}$ & $\begin{array}{l}\text { Number (and percent) } \\
\text { located in rural (districts) } \\
\text { areas: }\end{array}$ & $\begin{array}{l}\text { Number (and percent) } \\
\text { located in urban (cities) } \\
\text { areas: }\end{array}$ & $\begin{array}{l}\text { Total number of } \\
\text { non-bank MFIs: }\end{array}$ \\
\hline MCO & $28(82.4 \%)$ & $6(17.6 \%)$ & $34(22 \%)$ \\
CU & $85(70.2 \%)$ & $36(29.8 \%)$ & $121(78 \%)$ \\
\hline Total: & $113(73 \%)$ & $42(27 \%)$ & $155(100 \%)$ \\
\hline \hline
\end{tabular}

Source: Authors' calculations based on official statistics. The data is as of 2011. MCO stands for Microcredit Organizations, which in Uzbekistan represent Grameen-type lending groups operating under joint liability and a small collateral requirement with dynamic incentives. Credit unions (CUs) in Uzbekistan are open to the general public and are not limited to a defined, closed membership group.

The propensity score matching employed in this paper is based on covariates measured using retrospective questions obtained from a cross-section survey conducted by one of the authors (see Alimukhamedova, 2014). These retrospective covariates enable us to control for initial conditions that should have determined the decision of borrowers to apply for microcredit.

In the context of microfinance there are only a few studies that use such retrospective data. McIntosh et al. (2011) surveyed households in Guatemala to examine the effect of access to microcredit on dwelling improvement. They included major diseases, deaths, school enrolments, and major asset purchases among memorable events and find that access to microfinance caused a small but positive increase in the probability of housing improvement. Becchetti \& Castriota (2011) evaluated the effectiveness of microcredits as a post-tsunami 
recovery tool in Sri Lanka during four retrospective periods and found that microloans obtained after the tsunami had a positive and significant effect on both real income and hours worked. Becchetti \& Conzo (2014) asked retrospectively about the years of schooling and age of children of microfinance borrowers and a comparison group of non-borrowers in Buenos Aires, finding a positive and significant effect of microcredit on children's schooling. Retrospective data collection is always difficult because measurement error due to recall inaccuracy can be problematic. This is directly linked to an understanding of the structure of autobiographical memory and understanding the type of information that is being recalled retrospectively. ${ }^{9}$ We employ a standardized interview method whereby retrospective questions are embodied in a larger survey. These questions ask about the year of and cost incurred for particular, psychologically significant, discrete events that should be easily remembered. ${ }^{10}$ Accuracy of recall was enhanced through the use of timelines, public landmarks ${ }^{11}$ and careful training of interviewers. Based on local traditions, the following fundamental events were related to the use of microcredits: (i) weddings and other family ceremonies; (ii) housing renovation and construction; and (iii) purchase of major consumer durables. $^{12}$ A retrospective borrowing history (i.e. loan amount, interest paid, maturity,

\footnotetext{
9 In particular, there are hierarchical thematic and temporal structures that define human memory and mechanisms of recall: (i) lifetime periods that reflect long-term extended events and, thematic divisions of one's autobiography (ii) general events consisting of short-term extended events and summarized events (lifetime periods that nest general events) and (iii) episodic memories consisting of a pool of detailed sensations and perceptions (Conway and Pleydell-Pearce, 2000).

${ }^{10}$ As a matter of pride and self-esteem respondents were keen to share and therefore easily recalled weddings of their children and the acquisition of consumer durables. This suggests that inaccurate recall is likely to be small and, where it exists, unrelated to access to microfinance institutions.

11 It is a tradition in Uzbekistan to proclaim each calendar year with a particular social agenda, which is promoted heavily throughout the whole year and is uniform across regions. Therefore, for each retrospective question, respondents were reminded by the corresponding "public landmark." For example, 2014 was proclaimed "The Year of the Healthy Child" while 2015 is "The Year of the Elders." The year 2011 when the survey took place was proclaimed as the "Year of small business and private entrepreneurship"

12 The list of consumer durables comprised 12 items including furniture, major household appliances (i.e. TV, audio-video appliances, washing and sewing machines, microwaves, refrigerators, computer, satellite), vehicles, livestock and poultry. The list is also in line with national poverty indicators. These items correspond to a national indicators that measure a household's assets and wealth. Similar indicators have been developed and used for national household survey on family assets mobilization study (CER, 2011, p.39-40).
} 
collateral pledged) from formal (banks, MCOs, CUs) and informal (friends, relatives, moneylenders) financial sources was also collected.

The validity of the conditional independence assumption (CIA) and overall matching quality is directly linked to appropriate inclusion and exclusion of covariates. Matching built on CIA requires that outcome variables must be independent of treatment conditional on the propensity score. Therefore, implementing matching requires the choice of a set of variables that credibly satisfy this condition (Caliendo \& Kopeinig, 2008). Neither too many covariates, nor a too "trimmed" model is recommended. We match households in the nearest distance quartile from an MFI with those in the furthest quartile based on: (1) age of the household head; (2) gender of the household head; (3) education level of the household head (dummies for secondary, vocational or tertiary education); (4) interactions of the gender and education of the household head; (5) one and two year lags of expenditures on weddings and other major family events; ${ }^{13}(6)$ one and two year lags of wealth and (7) population density of the locality where the family lives.

\section{Data Collection and Descriptive Statistics}

The data was collected during January-March 2011 in three regions of Uzbekistan. Given the absence of donor-funded microfinance programs by the period when the data was collected, all CUs and MCOs exist for commercial purposes and their geographical distribution is quite uneven. The survey regions were chosen based on the density and maturity of MFIs and included the capital city of Tashkent (72 non-bank MFIs (46\% of the total in the country)), Tashkent region (16 non-bank MFIs), and Fergana region (25 non-bank MFIs).

\footnotetext{
${ }^{13}$ The choice of two lags was made to allow for short-term smoothing and ensure that the matching achieved $100 \%$ support. We recognize that including such a control may bias our results downward if families knowledge of future access to financial institutions affects their propensity to spend in prior periods, but this seems better than the alternative of omitting the available proxies for family wealth
} 
These regions were selected primary based on having a high density of non-bank MFIs, and population, while still including some more remote areas of the country. To better visualize the location of MFIs in regions we provide a map where survey regions are highlighted in dark in Figure 1.

Figure 1. A. Capital Tashkent and Tashkent region. B. Fergana region

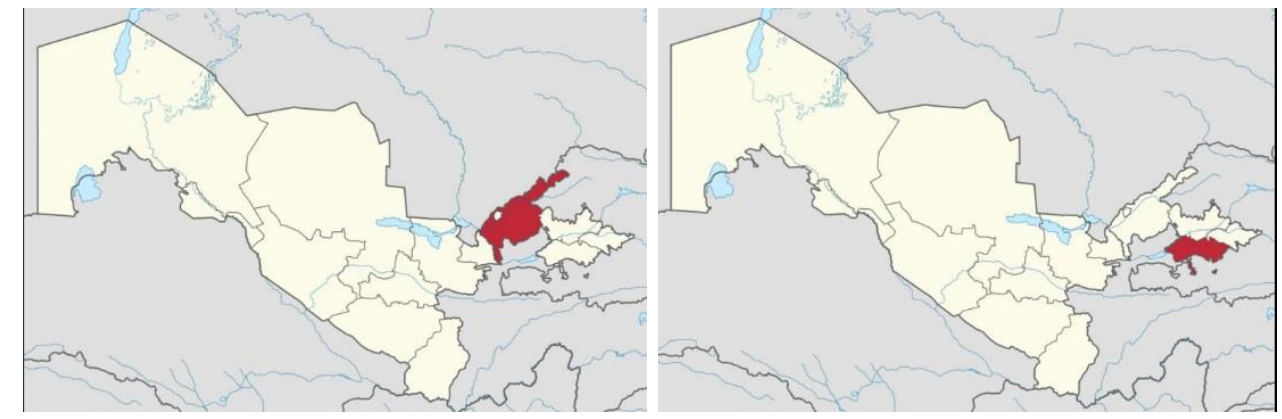

Overall, these three survey regions account for $72 \%$ of all MFIs in the country. See Alimukhamedova (2014) for further details.

The survey included two groups of respondents:

(A) Borrowers. In each of the three survey regions, the CU and the MCO having the largest asset base was selected for inclusion in the analysis. The borrower's group consisted of 100 randomly chosen active clients from each MFI.

(B) Non-borrowers. A comparison group of non-borrowers was composed of two subgroups: (a) non-borrower entrepreneurs, identified as individuals who have entrepreneurial activities but no formal or informal credit and (b) non-borrower households without entrepreneurship activities. For the non-borrowing groups a multi-stage random quota sampling was used. Among randomly selected villages a pre-determined walk pattern was established. Each household was administered a preliminary question to determine whether they were engaged in entrepreneurial activity and assigned to an interview group based on their response. Interviews were conducted within each group until the assigned quota was filled, with attention given to matching the borrowing sample with respect to household demographics. 
In each household the respondent was the household head, defined as the most knowledgeable person in the family of an economically active age. ${ }^{14}$ The total sample size was 1,086 observations. The distribution of the sample across the four types of respondents is in Table 2.

Table 2. Respondent Groups and Sample Sizes

\begin{tabular}{|c|c|c|c|}
\hline Respondents: & Definition: & Sampling: & Sample size: \\
\hline \multirow[t]{2}{*}{$\begin{array}{l}\text { Borrowers' } \\
\text { Group }\end{array}$} & $\begin{array}{l}\text { Borrower of } \\
\text { Microcredit } \\
\text { Organization [MCO] }\end{array}$ & $\begin{array}{l}\text { microcredit borrowers who have been active over the past } \\
\text { few years }\end{array}$ & 224 [21\%] \\
\hline & $\begin{array}{l}\text { Borrower of Credit } \\
\text { Union }[\mathrm{CU}]\end{array}$ & $\begin{array}{l}\text { microcredit borrowers who have been active for the past } \\
\text { few years }\end{array}$ & $262[24 \%]$ \\
\hline \multirow{3}{*}{$\begin{array}{l}\text { Non- } \\
\text { Borrowers } \\
\text { Group }\end{array}$} & $\begin{array}{l}\text { Non-borrower } \\
\text { entrepreneur }\end{array}$ & $\begin{array}{l}\text { respondent was identified as an individual engaged in } \\
\text { entrepreneurship activity that generates profit and assumes } \\
\text { self-employment }\end{array}$ & 312 [29\%] \\
\hline & $\begin{array}{l}\text { Non-borrower } \\
\text { household w/o } \\
\text { entrepreneurship } \\
\text { activity }\end{array}$ & $\begin{array}{l}\text { respondent was identified as the household head - the most } \\
\text { knowledgeable person in the family of an economically } \\
\text { active age [for women 18-55 years old, for men } 18-60 \text { years } \\
\text { old] }\end{array}$ & 288 [27\%] \\
\hline & & Total: & $1086[100 \%]$ \\
\hline
\end{tabular}

Source: Authors' calculations based on Uzbekistan survey. The data were collected during January-March, 2011.

Table 3 summarizes the location of the respondents across four distance quartiles including those living nearest (first quartile) and farthest (fourth quartile) from a non-bank MFI. As discussed above, our impact assessment will assume that respondents in the first distance quartile have easier access to microcredit. We derive the distance to nearest nonbank MFI in kilometres from a respondent's resident location. Given that exact location of all MFIs in districts and cities was known, we derived the distance based on respondent's address. Although we cannot be sure that a person borrows from the nearest MFI, the are substantial additional travel costs associated with borrowing from an MFI located at a greater distance makes use of the nearest MFI likely if there is any use at all. A pilot survey revealed that travel cost is an important issue both for clients and for MFI personnel who have to monitor and conduct on-site supervision of client premises before issuing microcredits. In addition, MFIs have strict policies of not issuing loans to clients residing in a different region.

\footnotetext{
${ }^{14}$ Defined as 18-55 years old for women and 18-60 years old for men. The upper age limit varies across gender because of differing statutory ages for pension eligibility.
} 
Table 3. Distance to Nearest MFI.

\begin{tabular}{|c|c|c|c|c|c|c|c|}
\hline \multirow[b]{2}{*}{$\begin{array}{l}\text { Distance } \\
\text { Quartile: }\end{array}$} & \multicolumn{2}{|c|}{ Distance } & \multicolumn{2}{|c|}{ Borrowers' group: } & \multicolumn{2}{|c|}{ Non-borrowers' group: } & \multirow[b]{2}{*}{ Total: } \\
\hline & $\begin{array}{l}\text { Mean } \\
{[\mathrm{km}]}\end{array}$ & $\begin{array}{l}\text { Std. } \\
\text { dev. }\end{array}$ & $\begin{array}{c}\text { MCO } \\
\text { borrowers }\end{array}$ & $\begin{array}{c}\mathrm{CU} \\
\text { borrowers }\end{array}$ & $\begin{array}{l}\text { Non-borrowers, } \\
\text { with } \\
\text { entrepreneurship }\end{array}$ & $\begin{array}{c}\text { Non-borrowers, } \\
\text { w/o } \\
\text { entrepreneurship }\end{array}$ & \\
\hline 1 [nearest] & 3.9 & 1.4 & $\begin{array}{c}55 \\
{[20 \%]}\end{array}$ & $\begin{array}{c}101 \\
{[37 \%]}\end{array}$ & $\begin{array}{c}59 \\
{[22 \%]}\end{array}$ & $\begin{array}{c}59 \\
{[22 \%]}\end{array}$ & $\begin{array}{c}274 \\
{[100 \%]}\end{array}$ \\
\hline 2 & 15.5 & 8.0 & $\begin{array}{c}100 \\
{[37 \%]}\end{array}$ & $\begin{array}{c}89 \\
{[32 \%]}\end{array}$ & $\begin{array}{c}42 \\
{[15 \%]}\end{array}$ & $\begin{array}{c}43 \\
{[16 \%]}\end{array}$ & $\begin{array}{c}274 \\
{[100 \%]}\end{array}$ \\
\hline 3 & 50.5 & 12.8 & $\begin{array}{c}24 \\
{[9 \%]}\end{array}$ & $\begin{array}{c}35 \\
{[12 \%]}\end{array}$ & $\begin{array}{c}125 \\
{[45 \%]}\end{array}$ & $\begin{array}{c}95 \\
{[34 \%]}\end{array}$ & $\begin{array}{c}279 \\
{[100 \%]}\end{array}$ \\
\hline 4 [farthest] & 87.5 & 22.6 & $\begin{array}{c}45 \\
{[17 \%]} \\
\end{array}$ & $\begin{array}{c}37 \\
{[14 \%]} \\
\end{array}$ & $\begin{array}{c}86 \\
{[33 \%]} \\
\end{array}$ & $\begin{array}{c}91 \\
{[35 \%]}\end{array}$ & $\begin{array}{c}259 \\
{[100 \%]}\end{array}$ \\
\hline Total & & & $\begin{array}{c}224 \\
{[21 \%]} \\
\end{array}$ & $\begin{array}{c}262 \\
{[24 \%]} \\
\end{array}$ & $\begin{array}{c}312 \\
{[29 \%]} \\
\end{array}$ & $\begin{array}{c}288 \\
{[26 \%]} \\
\end{array}$ & $\begin{array}{c}1,086 \\
{[100 \%]} \\
\end{array}$ \\
\hline
\end{tabular}

Note: The total number of observations was equal to 1,086. For each distance and type of the microfinance institutions we provide the associated number of observations [percent].

As can be seen in Table 4, there are significant differences in family characteristics across distance quartiles, thus indicating that matching in order to remove background effects on the outcome measures is important in assessing impacts.

Table 4. Means of main variables in by distance quartiles

\begin{tabular}{|c|c|c|c|c|c|c|}
\hline & \multirow{2}{*}{ Variables: } & \multicolumn{5}{|c|}{$\begin{array}{l}\text { Variable mean across four quantiles of } \\
\text { distance to nearest MFI }\end{array}$} \\
\hline & & $\begin{array}{c}1 \\
\text { nearest }\end{array}$ & 2 & 3 & $\begin{array}{c}4 \\
\text { farthest }\end{array}$ & Total: \\
\hline Distance & $\begin{array}{l}\text { Distance from household residence to } \\
\text { the nearest non-bank MFI }\end{array}$ & 4.06 & 16 & 49.8 & 92.7 & 39.1 \\
\hline \multirow{3}{*}{ Demographics } & Respondent age [years] & 39 & 41 & 43 & 40 & 41 \\
\hline & Female dummy & 0.62 & 0.41 & 0.35 & $0.40 * * *$ & 0.45 \\
\hline & Household size & 4.23 & 4.75 & 5.33 & $5.00 * * *$ & 4.82 \\
\hline \multirow{4}{*}{ Education } & Basic secondary education & $\mathbf{0 . 0 5}$ & 0.05 & 0.05 & $\mathbf{0 . 0 3} * * *$ & 0.04 \\
\hline & Complete secondary education & 0.25 & 0.23 & 0.27 & $0.30 * * *$ & 0.26 \\
\hline & Secondary vocation education & 0.38 & 0.38 & 0.46 & $0.48 * * *$ & 0.42 \\
\hline & Higher education & 0.32 & 0.34 & 0.23 & $0.17 * * *$ & 0.27 \\
\hline \multirow{4}{*}{ Behavioural } & Financial literacy & 12.0 & 12.0 & 11.8 & $10.7 * * *$ & 11.6 \\
\hline & Trust to MFIs & 0.61 & 0.66 & 0.33 & $\mathbf{0 . 5 0} * * *$ & 0.53 \\
\hline & Locus of control & 0.23 & 0.13 & 0.17 & $0.15 * * *$ & 0.17 \\
\hline & Risk aversion & 0.45 & 0.51 & 0.47 & $0.47 * * *$ & 0.47 \\
\hline \multirow{5}{*}{$\begin{array}{l}\text { Lagged } \\
\text { covariates: all } \\
\text { in ['000 UZS] }\end{array}$} & (1) Household wealth, -1 lag & 992 & 1645 & 695 & $1903 * * *$ & 1299 \\
\hline & (2) Household wealth, -1 lag & 551 & 743 & 351 & 271 & 479 \\
\hline & (3) Household wealth, -1 lag & 236 & 244 & 145 & 97 & 181 \\
\hline & Wedding expenditures, -1 lag & $\mathbf{1 , 1 1 0}$ & 436 & 691 & 551 & 517 \\
\hline & Construction expenditures, -1 lag & 346 & 373 & 451 & $312 * *$ & 371 \\
\hline
\end{tabular}

Notes: We employed three different definitions of household wealth: (1) Household wealth is a sum of household assets + housing + family business assets, (2) Household wealth is a sum of household assets + housing and finally, (3) Household wealth is just a sum of household assets. All financial covariates are provided in thousands of Uzbek soums (the official exchange rate was $1 \$=1,680$ in March, 2011).

$*, * *, * * *$ denote that mean in the $4^{\text {th }}$ quartile is significantly different from that in the $1^{\text {st }}$ quartile at the $10 \%, 5 \%$ and $1 \%$ levels, respectively. 


\section{Results}

The primary result is that greater access to microcredit has a positive and highly significant impact on business revenue and profits as well as (although at a lower level of significance) employment. Table 5 summarizes the differences in means across matched households for business enterprise outcomes such as revenue, profit and size captured by the number of employees during calendar 2010. It should be stressed that given the retail and family nature of business run by clients of non-bank MFIs, most households conduct their entrepreneurship activities in the same districts where they reside.

Table 5. Effect of Greater Access to Microcredit on Business Outcomes

\begin{tabular}{lcccc}
\hline \multirow{2}{*}{ Outcome } & \multicolumn{2}{c}{ All households } & \multicolumn{2}{c}{ Agriculture - Primary business } \\
\cline { 2 - 5 } & $\begin{array}{c}\text { \% on- } \\
\text { support }\end{array}$ & $\begin{array}{c}\text { ITT effect } \\
\text { (SE bootstrapped) }\end{array}$ & $\begin{array}{c}\text { \% on- } \\
\text { support }\end{array}$ & $\begin{array}{c}\text { ITT effect } \\
\text { (SE bootstrapped) }\end{array}$ \\
\hline \hline [1] Business revenue & 99.9 & $\begin{array}{c}16,019 * * * \\
(3,379)\end{array}$ & 99.9 & $\begin{array}{c}16,298^{* * *} \\
(5,152)\end{array}$ \\
[2] Business profit & 99.9 & $\begin{array}{c}4,929 * * * \\
(1,522)\end{array}$ & 99.9 & $\begin{array}{c}6,276^{* *} \\
(1,829)\end{array}$ \\
[3] Business size (employees) & 99.9 & $\begin{array}{c}0,38^{*} \\
(0,20)\end{array}$ & 99.9 & -0.18 \\
& & & & $(0.70)$ \\
[4] Business capital (assets) & 99.9 & $\begin{array}{c}2,250 \\
(3,318)\end{array}$ & 99.8 & $13,167 * * *$ \\
& & & & $(2,393)$ \\
[5] Labour productivity & $9,893^{* * *}$ & 99.8 & $13,711 * * *$ \\
& 99.9 & $(1,303)$ & & $(1,588)$ \\
\hline \hline
\end{tabular}

Notes: Business income, profits and capital are measured in thousands of Uzbek soums. Business capital (assets) is a sum of current market value (for total quantity) of buildings and premises, vehicles, equipment, agricultural machinery, stock, raw materials and inventory used in business.

Labour productivity is defined as business revenue divided by business employment.

The official exchange rate was $\$=1,680$ in March, 2011.

$*, * *, * * *$ denote $10 \%, 5 \%$ and $1 \%$ significance levels. Bootstrap standard errors are in parentheses and were derived from 100 replications.

Somewhat surprisingly, while the impact on business assets is positive, it is not statistically significant in non-agricultural businesses. This result may represent the less precise accuracy of asset measures when compared to income and employment figures. Overall, these results are in line with the findings of Banerjee, Duflo, Glennerster, and 
Kinnan. (2015) and Karlan and Zinman (2010), who find that business owners benefitting from access to credit are able to expand their enterprises.

Analysis of consumption is conducted at the household level, with results reported in Table 6. Dependent (outcome) variables represent average values for 2010. Among statistically equivalent households, better access to an MFI appears to have a positive and significant impact on most types of household consumption as well as total assets.

Table 6. Effect of Greater Access to Microcredit on Consumption

\begin{tabular}{lcc}
\hline \hline Expense Category & $\begin{array}{c}\text { \% on- } \\
\text { support }\end{array}$ & $\begin{array}{c}\text { ITT effect } \\
\text { (SE bootstrapped) }\end{array}$ \\
\hline \hline [1] Total HH expenses & 100 & $7,627^{* * *}$ \\
& 100 & $-1,212^{* *}$ \\
[2] Education expenses & 100 & $(382)$ \\
& & $1,50.6^{* * *}$ \\
[3] Health expenses & 100 & $1,977^{* * *}$ \\
& & $(205)$ \\
[4] Social expenses & 100 & $3,389^{* * *}$ \\
[5] Housing expenses & & $(652)$ \\
& 100 & $2,172^{* * *}$ \\
[6] Expenses on basic needs & & $(181)$ \\
& 100 & $48,262^{* * *}$ \\
[7] Total assets & & $(2545)$ \\
\hline
\end{tabular}

Notes: Expenses are measured in thousands of Uzbek soums. The official exchange rate was $1 \$=1,680$ in March, 2011. Total household expenditure is the sum of durable and non-durable expenditures, and does not include the credit repayment. $*, * * * * *$ denote $10 \%, 5 \%$ and $1 \%$ significance levels. Bootstrap standard errors are in parentheses and were derived from 100 replications.

This result is consistent with the theoretical predictions of Kaboski and Townsend (2012) of an overall increase in consumption from the availability of microcredits. The one exception to the pattern is the result that better access to microcredit appears to lower expenditures on education. Such a finding may result from entrepreneurs substituting physical capital (which can be used as collateral to facilitate a loan for human capital which is hard to borrow against. It is more likely, however, to simply reflect the co-location of feecharging secondary and tertiary educational institutions in the same geographic area as microfinance institutions. 
With respect to the role of distance to financial institutions on household consumption, our results are consistent with non-experimental impact studies of microfinance in countries broadly comparable to Uzbekistan. In particular, using household fixed-effects models Bangladesh Imai \& Azam (2012) found a positive and significant effect of microfinance loans on household income and food consumption. Chemin (2008) found a positive effect of microfinance loans in Bangladesh on household expenditure, labour supply and school enrolment levels using propensity score matching for impact assessment. Our findings are also consistent with other studies analysing the role of better geographical access to banking institutions such as Allen et al. (2013) in Kenya and Borwn at al.(2013) in Southeast Europe who found that better access to a banking institution significantly improved use of bank accounts and credits.

Within general microfinance impact studies, our results are consistent with the findings of experimental studies conducted by Banerjee at al. (2015) in India and Karlan \& Zinman (2010) in the Philippines. In these studies, the authors find that business owners benefitting from access to microcredit were able to expand their businesses. On household consumption patterns our findings of decreasing expenditures on education are similar to Banerjee at al. (2015) who found no significant changes in health, education, or women's empowerment after the establishment of a new microcredit program in Hyderabad, India.

\section{Conclusion}

We find that physical barriers to accessing financial institutions are significant. Based on a survey of 1086 microcredit borrowers and non-borrowers in Uzbekistan, better access to microcredit (measured by physical distance) has positive and significant effects on both business success and levels of consumption. Those with greater access run larger businesses, employ more workers (who are more productive) and earn greater profits. Households living closer to an MFI spend more in almost every consumption area yet also have greater 
accumulated assets (savings). The overall results reinforce the potential importance of expansion of access to finance for poor and near-poor households.

The raise the issue of potential trade-offs between opening microfinance institutions close to centers of economic activity or following the original pro-poor mission of locating inremote rural areas.

Our study helps to resolve prior conflicting evidence of the impact of microfinance. After addressing many of the methodological issues in accurately measuring the impact of such institutions, we find clear positive effects. A clear limitation of the study, however, is that these positive effects are found in the context of a microfinance system that targets existing entrepreneurs and those already above the poverty line..

\section{References}

Alessandrini, P., Fratianni, M., \& Zazzaro, A. (2009). The changing geography of banking and finance. Springer Verlag.

Alimukhamedova, N. (2012). Impact of non-bank micro-lending on business and welfare improvement. CERGE-EI Discussion Paper Series, 209, 1-41.

Alimukhamedova, N. (2014). Microfinance environment in Uzbekistan: analysis of supply and demand, Institute for East and Southeast European Studies (IOS Working Paper No. 344). Regensburg, Germany: Institute for East and Southeast European Studies.

Allen, F., Carletti, E., Cull, R., Qian, J., Senbet, L., \& Valenzuela, P. (2013). Improving access to banking: Evidence from Kenya (World Bank Working Paper No. 6593). Washington, DC: World Bank Policy Research

Angelucci, M., Karlan, D., \& Zinman, J. (2015). Microcredit impacts: Evidence from a randomized microcredit program placement experiment by Compartamos Banco. American Economic Journal: Applied Economics, 7(1), 151-182.

Armendariz, B., \& Labie, M. (2011). The Handbook of Microfinance. Singapore; Hackensack, NJ: World Scientific.

Armendariz, B., \& Morduch, J. (2010). The Economics of Microfinance (2nd. ed.). Cambridge, MA.: MIT Press.

Banerjee, A., Karlan, D., \& Zinman, J. (2015). Six randomized evaluations of microcredit: Introduction and further steps. American Economic Journal: Applied Economics, 7(1), 1-21.

Banerjee, A., Duflo, E., Glennerster, R., \& Kinnan, C. (2015). The miracle of microfinance? Evidence from a randomized evaluation. American Economic Journal: Applied Economics, 7(1), 22-53.

Barboza, G., \& Trejos, S. (2009). Micro credit in Chiapas, Mexico: Poverty reduction through group lending. Journal of Business Ethics, 88(2), 283-299. 
Bateman, M., \& Chang, H. J. (2009). The microfinance illusion. Retrieved from http://ssrn.com/abstract=2385174.

Bauchet, J., Marshall, C., Starita, L., Thomas, J., \& Yalouris, A. (2011, December). Latest findings from randomized evaluations of microfinance. In Access to finance forum (Vol. 2). Washington, DC: CGAP

Becchetti, L., \& Castiota, S. (2011). Does microfinance work as a recovery tool after disaster? Evidence from the 2004 tsunami. World Development, 39(6), 898-912.

Becchetti L., \& Conzo P. (2014). The controversial effects of microfinance on child schooling: A retrospective approach. Applied Financial Economics, 24(2), 89-106.

Brown, M., Guin, B., \& Kirschenmann, K. (2013). Microfinance banks and household access to finance (Working Papers on Finance No. 1302). Switzerland: University of St. Gallen.

Caliendo, M., \& Kopeinig, S. (2008). Some practical guidance for the implementation of propensity score matching. Journal of Economic Surveys, 22(1), 31-72.

Chemin, M. (2008). The benefits and costs of microfinance: evidence from Bangladesh. The Journal of Development Studies, 44(4), 463-484.

Conway, M A., \& Pleydell-Pearce, C. W. (2000). The construction of autobiographical memories in the self-memory system. Psychological Review, 107(2), 261-288.

Dehejia, R. H., \& Wahba, S. (2002). Propensity score-matching methods for nonexperimental causal studies. The Review of Economics and Statistics, 84(1), 151-161.

Demirguc-Kunt, A., Beck, T., \& Honohan, P. (2008). Finance for all?: Policies and pitfalls in expanding access. Washington, DC: World Bank Publications.

Demirguc-Kunt, A., \& Klapper, L. F. (2012). Measuring financial inclusion: The Global Findex database (World Bank Policy Research Working Paper No. 6025). Washington, DC: World Bank.

Gulli, H., \& Berger, M. (1999). Microfinance and poverty reduction - evidence from Latin America. Small Enterprise Development, 10(3), 16-28.

Hulme, D., \& Mosley, P. (1996). Finance against poverty. (Vol. 1,2). London, UK: Routledge.

Imai, K. S., \& Azam, M. S. (2012). Does microfinance reduce poverty in Bangladesh? New evidence from household panel data. The Journal of Development Studies, 48(5), 633-653.

Kaboski, J., \& Townsend, R. (2012). The impact of credit on village economies. American Economic Journal: Applied Economics, 4(2), 98-133.

Karlan, D., \& Godlberg, N. (2011). Microfinance evaluation strategies: Notes on methodology and findings. In B. Armendariz, \& M. Labie. (Eds.), The Handbook of Microfinance (pp. 17-58). Singapore; Hackensack, NJ: World Scientific.

Karlan, D., \& Zinman, J. (2010). Expanding credit access: Using randomized supply decisions to estimate the impacts. The Review of Financial Studies, 23(1), 433-464.

McIntosh, C., Villaran, G., \& Wydick, B. (2011). Microfinance and home improvement: Using retrospective panel data to measure program effects on fundamental events. World Development, 39(6), 922-937.

Oke, J. T., Adeyemo, O., \& Agbonlahor, M. U. (2007). An empirical analysis of microcredit repayment in Southwestern Nigeria. Humanities and Social Sciences Journal, 2(1), 63-74. 
Pedrosa, J., \& Do, Q. T. (2011). Geographic distance and credit market access in Niger. African Development Review, 23(3), 289-299.

Presbitero, A. F., \& Rabellotti, R. (2014). Geographical distance and moral hazard in microcredit: Evidence from Colombia. Journal of International Development, 26(1), 91-108.

Rosenbaum, R. R. \& Rubin, D. B, (1983). The central role of the propensity score in observational studies for causal effects. Biometrika, 70(1), 41-55.

Roslan, A., \& Karim, A. (2009). Determinants of microcredit repayment in Malaysia: The case of Agrobank. Humanities and Social Sciences Journal, 4(1), 45-52.

Smith, J. A., \& Todd P. E. (2005). Does matching overcome LaLonde's critique of nonexperimental estimators? Journal of Econometrics, 125(1), 305-353.

Tarozzi, A., Desai, J., \& Johnson, K. (2015). The impacts of microcredit: Evidence from Ethiopia. American Economic Journal: Applied Economics, 7(1), 54-89. 


\begin{abstract}
Abstrakt
(Zeměpisná) vzdálenost mezi domácností a finanční institucí může v rozvíjejících se zemích vytvářet výraznou překážku k využívání služeb finančních institucí. V tomto článku analyzujeme dostupnost mikro kreditů (měřeno geografickou vzdáleností) v Uzbekistánu. Porovnávali jsme srovnatelné domácnosti, které žijí blízko a ve větší vzdálenosti od institucí poskytujících mikro půjčky (pomocí „,propensity score matching“). Srovnatelné domácnosti, které jsou blíže finančním institucím, mají větší př́ijem z podnikání, zisk a více zaměstnanců, než srovnatelné domácnosti z větší vzdálenosti. Navíc domácnosti s dostupnějšími finančními službami více utrácejí ve většině kategorií své spotřeby a mají vyšší úspory.
\end{abstract}




\section{Working Paper Series}

ISSN 1211-3298

Registration No. (Ministry of Culture): E 19443

Individual researchers, as well as the on-line and printed versions of the CERGE-EI Working Papers (including their dissemination) were supported from institutional support RVO 67985998 from Economics Institute of the CAS, v. v. i.

Specific research support and/or other grants the researchers/publications benefited from are acknowledged at the beginning of the Paper.

(c) Nargiza Alimukhamedova, Randall K. Filer, and Jan Hanousek, 2016

All rights reserved. No part of this publication may be reproduced, stored in a retrieval system or transmitted in any form or by any means, electronic, mechanical or photocopying, recording, or otherwise without the prior permission of the publisher.

Published by

Charles University, Center for Economic Research and Graduate Education (CERGE)

and

Economics Institute of the CAS, v. v. i. (EI)

CERGE-El, Politických vězňů 7, 11121 Prague 1, tel.: +420 224005 153, Czech Republic.

Printed by CERGE-EI, Prague

Subscription: CERGE-EI homepage: http://www.cerge-ei.cz

Phone: + 420224005153

Email: office@cerge-ei.cz

Web: http://www.cerge-ei.cz

Editor: Jan Zápal

The paper is available online at http://www.cerge-ei.cz/publications/working_papers/.

ISBN 978-80-7343-384-0 (Univerzita Karlova, Centrum pro ekonomický výzkum a doktorské studium)

ISBN 978-80-7344-400-6 (Národohospodářský ústav AV ČR, v. v. i.) 
CERGE-EI

P.O.BOX 882

Politických vězňů 7

11121 Praha 1

Czech Republic http://www.cerge-ei.cz 